\title{
"Financial literacy as a moderator linking financial resource availability and SME growth in Ghana"
}

\begin{tabular}{|c|c|}
\hline \multirow{5}{*}{ AUTHORS } & Joseph Owusu (D https://orcid.org/0000-0001-6613-0084 \\
\hline & Mohammad Bin Ismail (D https://orcid.org/0000-0002-1063-8118 \\
\hline & Mohd Hassan Bin Mohd Osman \\
\hline & Garry Kuan iD https://orcid.org/0000-0003-1103-3871 \\
\hline & R http://www.researcherid.com/rid/H-4450-2016 \\
\hline ARTICLE INFO & $\begin{array}{l}\text { Joseph Owusu, Mohammad Bin Ismail, Mohd Hassan Bin Mohd Osman and } \\
\text { Garry Kuan (2019). Financial literacy as a moderator linking financial resource } \\
\text { availability and SME growth in Ghana. Investment Management and Financial } \\
\text { Innovations, 16(1), 154-166. doi:10.21511/imfi.16(1).2019.12 }\end{array}$ \\
\hline DOI & http://dx.doi.org/10.21511/imfi.16(1).2019.12 \\
\hline RELEASED ON & Thursday, 28 February 2019 \\
\hline RECEIVED ON & Thursday, 16 August 2018 \\
\hline \multirow[t]{2}{*}{ ACCEPTED ON } & Monday, 21 January 2019 \\
\hline & $(\mathrm{cc}) \mathbf{E Y}_{\mathrm{EY}}$ \\
\hline LICENSE & $\begin{array}{l}\text { This work is licensed under a Creative Commons Attribution } 4.0 \text { International } \\
\text { License }\end{array}$ \\
\hline JOURNAL & "Investment Management and Financial Innovations" \\
\hline ISSN PRINT & $1810-4967$ \\
\hline ISSN ONLINE & $1812-9358$ \\
\hline PUBLISHER & LLC "Consulting Publishing Company "Business Perspectives" \\
\hline FOUNDER & LLC "Consulting Publishing Company "Business Perspectives" \\
\hline
\end{tabular}

NUMBER OF REFERENCES

54

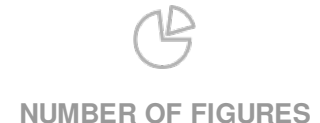

1
=:-

NUMBER OF TABLES

5

(C) The author(s) 2022. This publication is an open access article. 


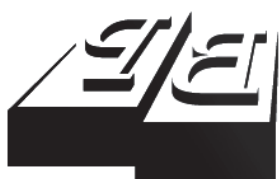

BUSINESS PERSPECTIVES

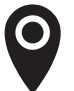

LLC "CPC "Business Perspectives" Hryhorii Skovoroda lane, 10, Sumy, 40022, Ukraine

www.businessperspectives.org

Received on: $16^{\text {th }}$ of August, 2018 Accepted on: $21^{\text {st }}$ of January, 2019

(C) Joseph Owusu, Mohammad Bin Ismail, Mohd Hassan Bin Mohd Osman, Garry Kuan, 2019

Joseph Owusu, Student, Faculty of Entrepreneurship and Business, Universiti Malaysia Kelantan, Malaysia.

Mohammad Bin Ismail, Associate Professor, Faculty of Entrepreneurship and Business, Universiti Malaysia Kelantan, Malaysia.

Mohd Hassan Bin Mohd Osman, Professor, Faculty of Entrepreneurship and Business, Universiti Malaysia Kelantan, Malaysia.

Garry Kuan, Senior Lecturer, School of Health Sciences, Universiti Sains Malaysia, Kubang Kerian, Kelantan, Malaysia.

\section{(ㄷ) (i)}

This is an Open Access article, distributed under the terms of the Creative Commons Attribution 4.0 International license, which permits unrestricted re-use, distribution, and reproduction in any medium, provided the original work is properly cited.

Joseph Owusu (Malaysia), Mohammad Bin Ismail (Malaysia),

Mohd Hassan Bin Mohd Osman (Malaysia), Garry Kuan (Malaysia)

\title{
FINANCIAL LITERACY
}

AS A MODERATOR LINKING

FINANCIAL RESOURCE

\section{AVAILABILITY AND SME GROWTH IN GHANA}

\begin{abstract}
The argument holds that visionary and dynamic small and medium enterprises (SMEs) tend to position growth at the centre of strategy. However, there has been a growing body of literature that has examined how financial literacy can support owner-managers of SMEs in making solid financial decisions that will enhance the growth of their businesses. In the present study, financial literacy and financial resource availability were modelled as different antecedents of SMEs growth. Nevertheless, the boundary condition for such models has received very little attention in the context of Ghana. Accordingly, in regard to resource-based view (RBV) logic, the current research examined the implications of contingency variable financial literacy (proficiency) on the relationship between financial resource availability and SMEs growth, particularly in the context of Ghana. The findings of the current research revealed that high financial literacy led to more positive effect of financial resource availability on SMEs growth.
\end{abstract}

Keywords

\section{JEL Classification L25, M13}

\section{INTRODUCTION}

The growth of small and medium enterprises (SME) is a major concern to every economy considering their enormous contribution to socioeconomic development. It is important to note that financial resource is often hyped as fundamental to SME growth. In addition, the existing literature postulates that the availability of financial resource is among the key challenges that need to be faced by entrepreneurs. According to Dollinger (1999) and Coleman (2007), financial resource availability is considered as the highest generic type of organizational means that can be changed into other forms of resources. On a similar note, George (2005) argues that financial resource availability is a utilizable monetary asset that can be deployed or converted by a firm in achieving its target objectives. In regard to this matter, it becomes necessary for entrepreneurs to secure adequate monetary funding to ensure promising growth and performance of their enterprises. However, lack of financial resources had been regarded as one of the major constraints that militate against the performance of SMEs, particularly amongst developing economies (Beck et al., 2008; Demirguc-Kunt et al., 2013). Hence, this circumstance has created a critical challenge that prevents the entrepreneurs from meeting their expected business growth. Certainly, the lack of monetary funding adversely affects entrepreneurs in their attempt to funding long- 
term lucrative ventures. More importantly, a broader standpoint of this issue seems to suggest that entrepreneurs are not able to undertake any meaningful economic activity under this condition due to the inability to raise sufficient monetary funding.

Previous researches have established a significant relationship between financial resource availability and firm performance (e.g. Cooper et al., 1994; Wiklund \& Shepherd, 2005; Adomako \& Danso, 2014). However, previously published studies on the effect of financial resource availability on SMEs growth are not consistent despite the attention given by the scholarly community. Hence, the present study makes an important move by addressing the lack of studies on this matter by investigating a number of specific underlying hypotheses. Therefore, the current research argues that there is a possible direct impact of financial resource availability on SME growth in regard to the monetary proficiency level of entrepreneurs. Overall, the purpose of the present study is to investigate the performance implications of monetary proficiency on the association between financial resource availability and SME growth. In addition, the current research also examines the extent to which monetary proficiency enhances the relationship between financial resource availability and SME growth in the context of Ghana. In an attempt to answering this question, the relationship between financial resource availability and SME growth is first established, followed by the contingency role of monetary proficiency on financial resource availability and SME growth association.

\section{THEORETICAL BACKGROUND}

The resource-based view (RBV) theory is used in the present study for the purpose of guiding and explaining the relationship between financial resource availability and SME growth, as well as the performance implication of monetary proficiency. Moreover, the present study relied on RBV to extend the available knowledge on these relationships which argued that monetary proficiency moderates the direct link between financial resource availability and SME growth. In addition, it was indicated that monetary proficiency has the capability to obtain and retain the necessary knowledge and skills to support financial resource availability with the aim of improving SME growth. Conceptually, the following related hypotheses were developed in reference to RBV: (1) financial resource availability and SME growth, and (2) financial resource availability, financial literacy, and SME growth.

The RBV concept that originated from Penrose (1959) indicates that a firm is capable of gaining competitive advantage over its competitors based on its method of organizing its resources, thus making it difficult for its competitors to duplicate its strategy (Penrose, 1959; Barney, 1991). Furthermore, the primary concept of RBV is centred on how firms package their resources in meeting the intended purpose in usage. Hence, $\mathrm{RBV}$ is regarded as an appropriate method that can be used when studying firm growth considering that it utilizes the organization as the unit of analysis. The prevailing stance (e.g. Barney, 1991; Barney \& Hesterly, 2012; Shafeey \& Trout, 2014) appear to state that RBV provides a comprehensive framework to explain how firms can achieve competitive advantage. On a similar note, Wernerfelt (1984) further argued that resources such as assets, finance, and capabilities of the organization play an important role in determining the success of an organization. According to Makadok (2001), capability is described as "a special type of resource-specifically and organizationally embedded non-transferable, firm-specific resources whose purpose is to improve the productivity of the other resources possessed by the firm". Notably, as suggested by Barney (1991) and Makadok (2001), both organizational resource and firm should possess the specific capabilities of complementing each other by focusing on the organizational effort to achieve superior performance. On a more important note, Barney (1991) postulates that the valuable and potential resources possessed by a firm should be idiosyncratic in nature as they serve as a prerequisite in obtaining significant competitive advantage. Hence, the firm stands to benefit from competitive advantage when competitors find it challenging to emulate or duplicate the 
resources. In the case of the present study, four conditions of the resource were established by the RBV theoretical framework which include beneficial, unique, exceptional, and utilizable by the organization (Barney, 1991), with the aim of exploring the capability of an asset to accomplish competitive advantage. Evidence abounds that resources with these unique qualities are highly promising and could be helpful in attaining competitive advantage (e.g. Barney, 1991; Barney \& Hesterly, 2012; Kozlenkova et al., 2013). Therefore, the present study analyzed the performance consequences of monetary proficiency based on RBV logic on the association between financial resource availability and SME growth in Ghana. Table 1 illustrates the contribution to GDP by the various SMEs sectors in Ghana.

Table 1. Various SMEs sector contributions to GDP in Ghana

\begin{tabular}{l|c|c|c|c|c} 
& \multicolumn{5}{c}{ Source: Ghana Statistical Service (2017). } \\
\hline \multicolumn{1}{c|}{ Sector } & $\mathbf{2 0 1 2}$ & $\mathbf{2 0 1 3}$ & $\mathbf{2 0 1 4}$ & $\mathbf{2 0 1 5}$ & $\mathbf{2 0 1 6}$ \\
\hline Agriculture & 31.8 & 29.8 & 25.3 & 23.0 & 22.0 \\
\hdashline Industry & 19.0 & 19.1 & 25.6 & 28.6 & 28.5 \\
\hdashline Service & 49.2 & 51.1 & 49.1 & 48.4 & 49.5 \\
GDP at basic price & 100.00 & 100.00 & 100.00 & 100.00 & 100.00 \\
\hline
\end{tabular}

\section{HYPOTHESES DEVELOPMENT}

\subsection{Financial resource availability and SME growth}

Financial resource availability has attracted significant interest from academic scholars over the years. Furthermore, many scholars have undertaken studies related to firm financial resource availability and managed to document a comprehensive association between financial resource availability and performance (e.g. Adomako \& Danso, 2014; Cooper et al., 1994; Wilklund \& Shepherd, 2005). Most importantly, a major outcome that surfaced from these studies indicated the significant relationship between financial resource availability and organizational performance. In regard to this matter, an empirical study conducted by Neneh (2016) on South Africa SMEs managed to discover a significant and positive correlation between financial capital availability and the performance of SMEs. Meanwhile, related literature seems to suggest that entrepreneurs with sufficient monetary assets are more likely to secure the most necessary assets for their firm operations (e.g. Atkas et al., 2015; Byrd, Ross, \& Clackin, 2013). Additionally, Atkas et al. (2015) contended that entrepreneurs who have limited monetary funding may not be able to undertake any meaningful lucrative investment ventures. For instance, adequate monetary funding enables owners of SMEs to secure all the necessary assets required for their operations. Hence, it could be further argued based on the preceding arguments that adequate monetary funding is uniquely relevant to SMEs in overcoming their monetary issues which have been restricting their execution and growth. Therefore, the importance of SMEs to have adequate monetary funding should never be taken lightly. In this case, the proposition that financial resource availability strongly influences SME growth was verified in the present study based on the following hypothesis:

H1: Financial resource availability is positively related to SME growth.

\subsection{Financial literacy, financial resource availability and SME growth}

In reference to RBV as a standpoint of departure, the present study attempts to enhance the idea of a firm growth benefits with the prominent competence of monetary proficiency as a unique intangible resource. In addition, this study addressed the question whether the impact of monetary proficiency on organization development is conditioned by financial resources availability in the context of SMEs from developing economies, particularly Ghana. More specifically, financial resource availability becomes more valuable when it is properly managed to produce good outcomes such as growth and performance (Miller et al., 2009; Adomako \& Danso, 2014). In regard to this, recent evidence (e.g. Lusardi \& Mitchell, 2013; Van Rooij et al., 2011; Adomako \& Danso, 2014) seems to suggest a strong correlation between monetary proficiency and monetary results. Meanwhile, the existing literature authenticated the fact that monetary proficiency serves as an important means in guiding the monetary matters of an organization (Lusardi \& Mitchell, 2013; Wiklund \& Shepherd, 
2005). Hence, in regard to this connection, it is strongly argued that monetary proficiency is definitely able to prevent the entrepreneurs from making any unsatisfactory monetary decisions (Campbell, 2006). Hence, it is important for entrepreneurs to be more aware of this, considering that their monetary proficiency plays an important role in determining and improving the necessary monetary insights that are helpful in creating estimated expenses, sales revenue, objective reporting, economical scheme, and imperative and monetary contributions decisions (Greenspan, 2002; Lusardi, 2008; Drexler et al., 2014). In the same manner, it could be further argued that entrepreneurs with prominent competence of monetary proficiency are more inclined to be highly progressive in the capital markets due to the reduction in information asymmetry (Campbell, 2006; Miller et al., 2009). In addition, the financial knowledge and financial skills of entrepreneurs tend to increase as a result of higher awareness of monetary proficiency (Hilgert et al., 2003; Lusardi et al., 2010). Therefore, the present study contended that it is crucial to regard monetary proficiency as a possible variable in the relationship between financial resource availability and SME growth in less matured economies that have been faced with the issue of poor monetary proficiency. The current research assumed that monetary proficiency positively enhances the relationship between financial resource availability and SME growth. Hence, it can be hypothesized that:

H2: In SMEs, the impact of financial resource availability on growth becomes more positive when entrepreneur financial literacy is high.

\section{METHODOLOGY}

\subsection{Sample and data collection}

Ghana as part of the economically developing nations in Sub-Saharan Africa is faced with lack of monetary assets that poses as a major constraint in the firm growth (Fjose, 2010; Beck et al., 2008; Demirguc-Kunt et al., 2013). Hence, this provides a rational explanation as to why Ghana was chosen as the subject of the present study which aimed to investigate the impact of financial resource availability on SME growth. In regard to this, the cur- rent research decided that it was ideal to focus on a single host country Ghana, particularly its service SMEs, for the purpose of preventing any potential effects from extraneous confounding variables that might come from legal, cultural, and other institutional settings. More importantly, service SMEs such as hotels, restaurants, transport, and storage were chosen for the analysis due to the following reasons. First, the Ghana Statistical Service (2016) stated that the service SMEs rank first in all the ten regions of the country in terms of business establishment based on economic sectors. Second, in Ghana, the service SMEs contribute the highest to Gross Domestic Product (GDP) compared to agriculture and industrial SMEs. Apart from that, it is critical to note that the service SME is the leading sector in the private sector of the Ghana economy, particularly in terms of employment generations, innovations, exports, as well as economic growth and development (GSS, 2016).

The present study used the multi-stage cluster sampling technique which involved a geographical stratification of the entire country into areas dominated by the service SMEs activities. In this case, three regional capital cities, namely Accra, Kumasi, and Sunyani, were deemed appropriate. Meanwhile, the SME definition provided by the Ghana National Board for Small Scale Industries (NBSSI) was adopted in the current survey which stated the fact that SMEs tend to operate from a fixed premises and employ between a total of 6 and 99 workers. In addition, three enumerators who were business graduate students from a local polytechnic in each region were hired and provided with the necessary training for the purpose of data collection. In the case of this study, the enumerators were thoroughly briefed on the geographical coverage of the study and provided with a list containing the information of the sampled SMEs obtained from the Ghana Statistical Service (GSS) headquarters in Accra which include their names, addresses, and telephone numbers for the purpose of distributing the questionnaires. Meanwhile, the respondents of the present study were selected based on several characteristics described as follows: (1) service SMEs that are registered, (2) SMEs which consist of a total number of 6 to 99 employees, (3) SMEs that have been established for more than three years, and (4) SMEs that are privately owned. Moreover, it is important to note that the questionnaires were self-administered 
with the assistance of the trained enumerators. On another note, the participants were assured about the confidentiality of their responses. Overall, a total number of 500 questionnaires were allocated to owner-managers and other entrepreneurs of service SMEs in several chosen regional capital cities of Ghana. Of the respondents who received the questionnaire across the selected regions, only 304 questionnaires were returned which represent $60.8 \%$ response rate. The positive feedback seems to suggest that the strategy of employing female enumerators to collect data from owner-managers and other entrepreneurs of SMEs was effective because they were highly welcomed. Nevertheless, an expediting action was performed using telephone to cross check the respondents for the purpose of authenticating the validity of the data collected. In this case, at least 15 to 20 respondents were randomly selected from each region to validate the responses. In the survey, the respondents were asked to provide their feedbacks on several questions in the questionnaire. The findings from the survey revealed that the feedbacks were in agreement with the real survey feedbacks. Therefore, this suggests that the participants provided valid feedbacks in the main questionnaire and were competent from a homogeneous population.

\subsection{Variables and measures}

\subsubsection{SME growth}

In the current research, SME growth is operated as the dependent variable. Similar to other previous survey studies (e.g. Delmer, 1997; Delmer et al., 2003; Storey, 1994), the current research also utilized the absolute measure of growth. Recent evidence (e.g. Davidsson et al., 2006; Wiklund \& Shepherd, 2005) discovered that a complete measure of growth is well associated with the perceptual measures of growth. Therefore, the researchers used 3-item measurement with seven-point Likert scale which was in the range of $1=$ strongly disagree to $7=$ strongly agree to capture the perception of respondents on firm growth.

\subsubsection{Financial resource availability}

On another note, financial resource availability is served as the independent variable tested in the current research. Financial resource availability is described as the entrepreneur's level of satisfaction regarding the access to monetary assets. The present study measured financial resource availability by 4 -subjective item measurement as suggested by past studies (Cooper et al., 1994; Wiklund \& Shepherd, 2005; Adomako \& Danso, 2014). These 4-subjective item measurement sought to examine SME the level of satisfaction of entrepreneurs regarding their approach to monetary assets. The researchers used four seven-point Likert scale items ranging from $1=$ strongly disagree to $7=$ strongly agree with the aim of obtaining the subjective views of the respondents regarding how they can obtain monetary assets that can help to strengthen their business operations.

\subsubsection{Financial literacy}

Financial literacy was tested as the moderating variable in the present study. More importantly, the current research relied on the similar survey to gather data that would be helpful in measuring the level of monetary proficiency among the entrepreneurs (Sucuahi, 2013; Fatoki, 2014; Adomako \& Danso, 2014). Moreover, these items were modified to suit the study context. The researchers used three seven-point Likert scale with the items being measure in the range of $1=$ strongly disagree to $7=$ strongly agree with the aim of obtaining the perceptions of the participant's level in regard to monetary proficiency.

\subsection{Control variables}

The current research used three controlled firmlevel variables, namely firm ownership type, firm age, and firm size based on the survey conducted by past studies (Yasuda, 2005; Wiklund et al., 2007; Wakkee et al., 2015). It is argued that the stylized fact of firm size has been revealed in the previous literature to have negative effect on firm growth (Yasuda, 2005; Bottazzi \& Secchi, 2003). Firm size is measured using the number of full time employees including owner-manager. Firm age may have impact on firm growth. Firm age is measured as the number of years in business. The negative effect of age on firm growth is consistent even among organizations and countries (Wiklund et al., 2007; Yasuda, 2005). Wakkee et al. (2015), disclose that firm ownership helps firms to benefit from financial capital and has positive effect 
on their growth. For ownership type (sole proprietor $=1$; others $=0$ ) were controlled. Therefore, it was necessary to control these variables alongside their theoretical construct of interest.

\section{ANALYSIS AND RESULTS}

\subsection{Reliability and validity constructs}

Table 2 presents the descriptive statistics which consist of mean, standard deviation, skewness, and kurtosis values for all variables (i.e. firm growth, financial resource availability, financial literacy, firm type, firm age, and firm size). Meanwhile, the number of items and Cronbach's alpha values are illustrated in Table 3 whereby all of the constructs display the values more than 0.7 , thus, suggesting that all items used in the present study are certainly reliable (Nunally, 1978). In addition, this study also assessed a unique measure of internal consistency reliability which was dapped as 'composite reliability'. Furthermore, it can be observed in Table 3 that all composite reliability values for each construct exceed 0.6, which further signifies the reaffirmation of study items reliability in measur- ing each theoretical construct. Next, the present study tested the three-factor confirmatory factor analysis model as suggested by Anderson and Garbing (1988) which manages to produce a good fit to the data as follows: $\chi^{2}=514.10$, $d f=296, \quad \chi^{2} / d f=1.74, \quad$ RMSEA $=0.05$, $\mathrm{NNFI}=0.95, \mathrm{CFI}=0.96$, while the value of the standardized root mean square residual (SRMR) is shown to be 0.05 . Apart from that, the items and their loadings, associate $t$-values, and average variance extracted (AVE) are also tabulated in the same table. Meanwhile, the good model fit indices particularly referring to the average variance extracted (AVE) is above 0.5, which further demonstrates the convergent validity of each study construct. Finally, the AVE values were compared with the shared variances between the constructs with the aim on analysing the discriminant validity (Hair et al., 2014). On another note, it can be concluded from Table 3 that the discriminant validity of each construct is supported because each of them is significant compared to the corresponding inter-construct squared correlations. Therefore, this further implies that the distinctiveness of the study constructs managed to capture the phenomenon that failed to be achieved by other measures.

Table 2. Descriptive statistics of the study constructs

\begin{tabular}{|c|c|c|c|c|c|c|}
\hline Variable & Min & Max & Mean & SD & Skewness & Kurtosis \\
\hline Firm growth & 1.00 & 7.00 & 4.55 & 1.27 & -0.44 & -0.40 \\
\hline Financial resource availability (FRA) & 1.00 & 7.00 & 4.68 & 1.31 & -0.43 & -0.26 \\
\hline Financial literacy $(\mathrm{FL})$ & 1.33 & 7.00 & 5.52 & 1.15 & -1.05 & 1.10 \\
\hline Firm type $($ sole proprietor $=" 1 ")$ & 0.00 & 1.00 & 0.53 & 0.50 & -0.13 & -2.00 \\
\hline Firm age & 1.10 & 3.87 & 2.05 & 0.66 & 0.05 & -0.46 \\
\hline Firm size & 1.00 & 5.00 & 2.49 & 1.26 & 0.34 & -1.04 \\
\hline
\end{tabular}

Note: $\mathrm{SD}=$ standard deviation.

Table 3. Confirmatory analysis results

\begin{tabular}{|c|c|c|c|c|c|c|}
\hline Construct & Items & Loading & $t$-values & CR & AVE & CA \\
\hline \multirow{3}{*}{ Firm growth } & Constantly growth in sales & 0.79 & Fixed & \multirow{3}{*}{0.79} & \multirow{3}{*}{0.55} & \multirow{3}{*}{0.78} \\
\hline & Has employed more people & 0.71 & 10.43 & & & \\
\hline & Consistent increase in the market value & 0.72 & 10.52 & & & \\
\hline \multirow{4}{*}{$\begin{array}{l}\text { Financial resource } \\
\text { availability }\end{array}$} & Continuous access to finance & 0.85 & Fixed & \multirow{4}{*}{0.85} & \multirow{4}{*}{0.59} & \multirow{4}{*}{0.84} \\
\hline & Available access to finance & 0.88 & 16.35 & & & \\
\hline & Easy access to finance & 0.69 & 12.48 & & & \\
\hline & Satisfactory level with its finances & 0.61 & 10.57 & & & \\
\hline \multirow{3}{*}{ Financial literacy } & Prepare daily sales records & 0.67 & Fixed & \multirow{3}{*}{0.81} & \multirow{3}{*}{0.59} & \multirow{3}{*}{0.80} \\
\hline & Manage working capital & 0.92 & 10.73 & & & \\
\hline & Make sound financial investment decision & 0.70 & 10.17 & & & \\
\hline
\end{tabular}

Notes: Loadings are significant at $1 \% ; \mathrm{CR}=$ Composite reliability, $\mathrm{AVE}=$ average variance extracted, $\mathrm{CA}=$ Cronbach Alpha. 


\subsection{Assessment of common method bias}

The present study examined whether common method bias (CMB) is sufficiently present in the data considering that data collected based on self-report survey may be infested with common method bias (Krishnan et al., 2006). As suggested by Podsakoff et al. (2003), a Herman one factor test was carried out and the findings revealed an extremely poor indication as follows: $\chi^{2}=6786.14 ; d f=495$; $\chi^{2} / d f=13.71 ; \quad$ RMSEA $=0.22 ; \quad$ NNFI $=0.28 ;$ $\mathrm{CFI}=0.32$; $\mathrm{SRMR}=0.18$. Next, further analysis was performed in order to test the CMB as suggested by Cote and Buckley (1987). In this case, a single factor was incorporated in each manifest indicator, thus producing a significant and better fit of the data given: $\chi^{2}=1093.71 ; d f=467$; $\chi^{2} / d f=2.34 ; \quad \Delta \chi^{2}(d f, p)=5692.43$ $(28, p<.001) ; \quad$ RMSEA $=0.07 ; \quad$ NNFI $=0.89$; $\mathrm{CFI}=0.91 ; \mathrm{SRMR}=0.07$. Therefore, these results have indicated and confirmed that common method bias was not a problem for the following hypothesis analysis.

\subsection{Measurement model analysis}

The hypotheses of the present study were tested in reference to several recent studies (e.g. Cadogan et al., 2013; Boso et al., 2013), particularly in regard to the impact of the interaction variable which tends to raise the issue of multicollinearity. The dominant view of Little, Bovaird, and Widaman (2006) describes that the failure to determine both external and internal variables will result in structural coefficient bias. In the present study, the hierarchical moderated regression was employed to analyse the hypotheses based on two approaches with the aim of evaluating the interrelationship be- tween financial resource availability, financial literacy, and SME growth. The first approach refers to the assessment of the structured variables, while the second approach involves the regression analysis that is incorporated with interaction terms nested in the main effect model. In this case, both the hypothesised and non-hypothesised control variables were incorporated together in the second model. Table 4 presents the results of the collinearity test obtained from the residual cantering method. As can be observed in the same table, all variables used in the regression estimate show a low variance inflation factor (VIF) which is less than the recommended threshold of 5.00 suggested by Hair et al. (2014). Hence, it can be verified that the variables in the regression estimate are effective in interpreting the results. On another note, the $\mathrm{H} 1$ of the current research hypothesised that there is a direct link between financial resource availability and SME growth. Meanwhile, model 2 shows a positive coefficient ( $\beta=0.25, t=4.14, p<0.001)$, which further indicates that $\mathrm{H} 1$ is supported. Additionally, $\mathrm{H} 2$ revealed that the positive effect of financial resource availability on SME growth is increased with high monetary proficiency. Meanwhile, the findings in model 2 confirmed that $\mathrm{H} 2$ is supported given $(\beta=0.25, t=4.37, p<0.001)$.

Figure 1 indicates the joint effect of financial resource availability and financial proficiency on SMEs growth. The findings suggest that SMEs with high levels of financial proficiency normally grow rapidly than SMEs with low levels of financial proficiency. Indicating that when firms have similar levels of financial resource availability, the firm with high levels of financial proficiency will outperform the firm with low levels of financial proficiency. This sup-

Table 4. Collinearity diagnostics using firm growth as the dependent variable

Source: Survey data.

\begin{tabular}{|c|c|c|c|c|c|c|c|c|c|}
\hline \multirow{2}{*}{ Variables } & \multirow{2}{*}{ Tolerance } & \multirow{2}{*}{ VIF } & \multirow{2}{*}{$\begin{array}{c}\text { Condition } \\
\text { Index }\end{array}$} & \multicolumn{6}{|c|}{ Variance proportion } \\
\hline & & & & 1 & 2 & 3 & 4 & 5 & 6 \\
\hline Financial resource availability & .85 & 1.17 & 3.74 & 0.00 & 0.00 & 0.00 & 0.91 & 0.00 & 0.01 \\
\hline Financial literacy & .86 & 1.16 & 5.69 & 0.02 & 0.01 & 0.01 & 0.00 & 0.02 & 0.89 \\
\hline Financial resource reliability & .84 & 1.19 & 4.45 & 0.03 & 0.16 & 0.01 & 0.00 & 0.56 & 0.12 \\
\hline Firm type (sole proprietor $=" 1 ")$ & .96 & 1.04 & 10.75 & 0.68 & 0.01 & 0.36 & 0.00 & 0.09 & 0.01 \\
\hline Firm age & .92 & 1.09 & 13.69 & 0.26 & 0.75 & 0.17 & 0.03 & 0.14 & 0.01 \\
\hline Firm size & 1.00 & 1.00 & 20.25 & 0.02 & 0.24 & 0.27 & 0.03 & 0.16 & 0.07 \\
\hline
\end{tabular}

Note: VIF = variance inflation factor. 
Table 5. Results of moderated regression analysis

Source: Survey data.

\begin{tabular}{|c|c|c|}
\hline Dependent variable: SME growth & Model 1 & Model 2 \\
\hline Control variables & - & - \\
\hline Firm ownership & $-0.13(-2.01)$ & $-0.09(-1.39)$ \\
\hline Firm age & $0.10(1.60)$ & $0.11(1.69)$ \\
\hline Firm size & $-0.05(-0.74)$ & $-0.05(-0.82)$ \\
\hline Main effect path & - & - \\
\hline Financial resource availability & $0.22(3.59)$ & $0.25(4.14)$ \\
\hline Financial literacy & $0.15(2.33)$ & $0.21(3.17)$ \\
\hline Moderating effect & - & - \\
\hline FRAYFL & - & $0.25(4.37)$ \\
\hline Goodness of fit indices & - & - \\
\hline$R^{2}$ & 0.301 & 0.344 \\
\hline$\Delta R^{2}$ & - & 0.48 \\
\hline Adj. $R^{2}$ & 0.278 & 0.312 \\
\hline$F$ statistics & 0.000 & 0.002 \\
\hline
\end{tabular}

Note: Standardized coefficients are reported ( $t$-values are in parentheses), significant levels ${ }^{*}=0.05 ;{ }^{* *}=0.01 ;(1=$ tail test).

ports the argument by Lusardi and Mitchell (2013) that sufficient financial capital alone without financial proficiency in managing the finance may not have significant effect on firm performance. This discloses that financial proficiency is an important intangible resource for firm growth. Financial proficiency influences financial outcomes of a firm simply because it is an important tool for steering the financial affairs of a firm (Lusardi \& Mitchell, 2013; Wiklund \& Shepherd, 2005). Because of this steering effect, financial proficiency serves as a moderating variable that enhances the association between financial resource availability and SMEs growth.

\section{DISCUSSION AND IMPLICATIONS}

The purpose of this paper was to expand the knowledge on the moderating role of monetary proficiency in regard to the relationship between financial resource availability and SMEs growth. The present study assessed the strong relationship between financial resource availability and SMEs growth, as well as the possible moderating role of monetary proficiency. Moreover, the objective of the current research was to widen the body of knowledge of venture capitalism and scheme by simplifying this relationship. Accordingly, the impact of financial resource availability and mon-

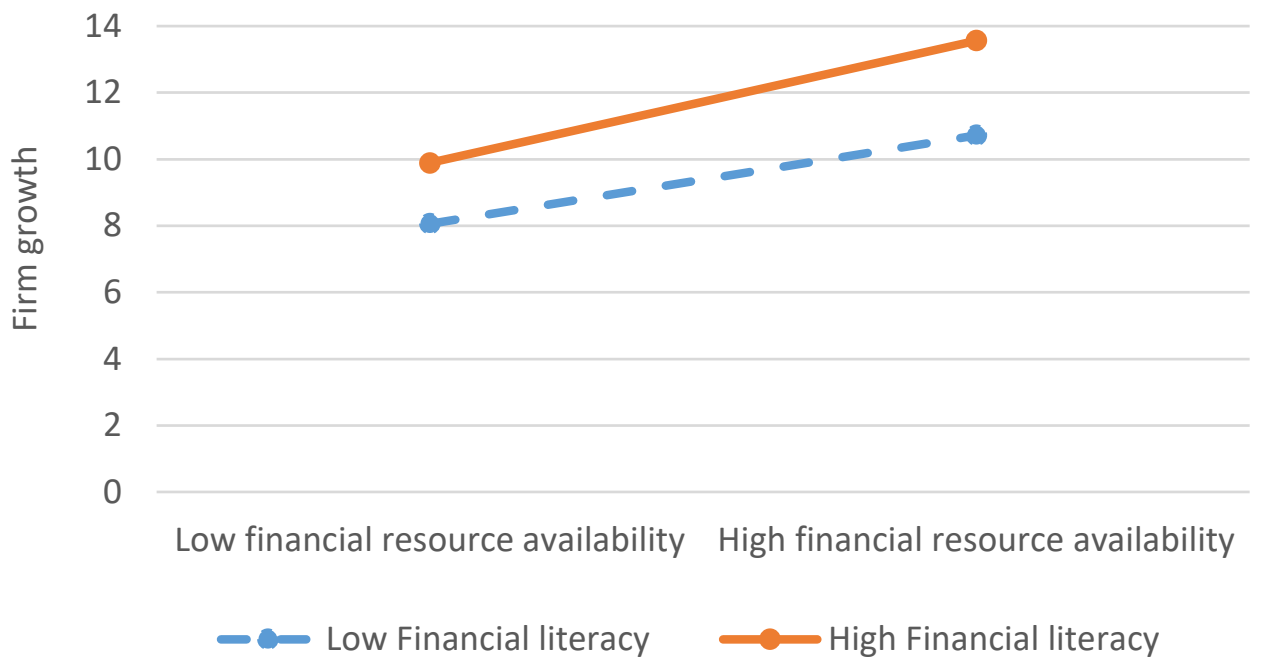

Figure 1. The joint effect of financial resource availability and financial literacy on firm growth 
etary proficiency on growth was developed. In regard to this matter, a considerable amount of literature indicates that organizations with sufficient monetary assets are more inclined to enhance their progress (Cooper et al., 1994; Wiklund \& Shepherd, 2005). Nevertheless, it has been argued that there has been limited reliable evidence in regard to the relationship between financial resource availability and growth, especially in countries with underdeveloped economies such as Ghana. Moreover, the edge conditions for this particular model have not been properly managed based on the unique context in Ghana. Meanwhile, the current research developed a number of hypotheses for the purpose of analyzing the arguments in this study. The findings revealed the following: (1) financial resource availability has a positive and significant effect on SMEs growth, which indicates that $\mathrm{H} 1$ is supported, and (2) the impact of financial resource availability on SMEs growth become more positive when the monetary proficiency of entrepreneurs is high, thus implying that $\mathrm{H} 2$ is supported. Hence, the present study opined that monetary proficiency was able to enhance SMEs growth, particularly when entrepreneurs possess available monetary budgets. These findings amplifier the notion that monetary proficiency is a contingency factor and those who are monetary proficient will be able to enhance the progress of their business by taking into account this possible factor. The findings of the current research have numerous logical and organizational consequences that are further explained in the following subsections. Theoretical and managerial implications are elaborated below.

\subsection{Theoretical implications}

The current research provides several contributions to the growing body of literature from the theoretical standpoint, particularly in SMEs financing and growth under the entrepreneurship and strategy literature. First, the direct effect of financial resource availability on SMEs growth shed new insights on the distinctive characteristics of monetary assets which serve as a crucial element in organisational performance (Cooper et al., 1994; Wiklund \& Shepherd, 2005; Adomako \& Danso, 2014). In addition, the results also indicated that financial resource availability acts as a predictor of firm growth. The absence of this calibre of study, particularly the entrepreneurship theory, was unable to reveal fresh perspective on the task of financial resource availability on SMEs growth in less developed economy such as Ghana. The significant contribution here refers to the possibility that scholars can incorporate the role of financial resource availability in future works, especially when SMEs report superior growth. Next, another theoretical implication of this study is that growth is one strategy of SMEs internationalization prescribe as dynamic and evolutionary process for the firm (e.g. Dobbs \& Hamilton, 2007; Aldrich, 1999; Scot \& Bruce, 1987). Internationalization of SMEs can be achieved through the resources control by the firm (Barney, 1991; Wernerfelt, 1984). RBV is centred on firm resources both tangible and intangible such as financial resources and capabilities (Gupta et al., 2013; Yazdanfar \& Habib, 2016). From a perspective of RBV, for any firm to have better performance largely depends on the quality resources it's possesses and how uniquely the resources are mixed to enhance its competitive advantage (Barney, 1991; Gupta et al., 2013; Yazdanfar \& Habib, 2016). Accordingly, with reference to RBV as a point of departure, in Ghana, as SMEs gradually learn to build up financial resources and develop financial proficiency under their control, they intend to support the internationalization of these SMEs as a major growth strategy with the liberalized international marketplace. On this front, through SMEs internationalization the economy growth of the nation can be boosted (EC, 2007). Moreover, SMEs internationalisation could facilitates its operations in the foreign market or give global exposure through increase their awareness, increase in expansion of firm relationship and network, and accumulations of knowledge (Beamish, 1990). The third theoretical implication is that the current research managed to clarify why monetary proficiency is very important by indicating its moderating role, especially for entrepreneurs who possess adequate financial resources. Therefore, the present study highly concluded that monetary proficiency further strengthens the association between financial resource availability and SMEs growth. The implication is that failure to acknowledge the moderating role of monetary proficiency will slightly restricts a very vital contribution to entrepreneurship and strategy literature. Hence, the possible role of monetary proficiency was investigated in this study. 


\subsection{Managerial implications}

Previous studies have suffered from the lack of discussion on the notion that financial resource availability predicts SMEs growth. Hence, the current research extended this investigation by further exploring the underdeveloped country. Additionally, the moderating role of monetary proficiency on the association between financial resource availability and SMEs growth was examined in this study. Consequently, this study managed to establish the crucial role of financial resource availability and monetary proficiency in enhancing SMEs growth in the context of a developing country. In regard to this, from a practical standpoint, it is recommended for owner-managers and policy makers to be more aware of financial resource availability and emphasise more on the techniques that can help to manage monetary assets effectively. Apart from that, it is also crucial for the government to assist entrepreneurs in developing their financial literacy capabilities with the purpose of managing and making good financial decisions to support their businesses. Furthermore, this development would require government to organize financial literacy education and training for owners of SMEs. On another note, it is suggested for the owner-managers of SMEs to develop their monetary assets together with monetary proficiency. Overall, it is hoped for those SMEs owners to concentrate on monetary assets and take into account the importance of monetary proficiency to ensure that growth can be achieved. Nonetheless, the findings of this study revealed that superior growth can be achieved when entrepreneurs are highly monetary proficient.

\section{LIMITATIONS AND RECOMMENDATIONS FOR FUTURE RESEARCH}

In regard to the findings and research methods of the current study, some limitations need to be acknowledged and addressed. First, it is necessary for future works to control some variables that can affect the growth outcome (e.g. firm ownership, firm size, and firm age), because this study failed to control other potential and influential covariates that were incorporated in past research such as environmental munificence and dynamism (Eisenhardt \& Tabrizi, 1995). Consequently, this impacted the clear observation concerning the relationship between financial resource availability and SMEs growth in the present study. Nevertheless, this open future opportunities for academic scholars to further explore the field of this study. Second, the generalizability of these findings was limited, because the sample data were only obtained from service SMEs in Ghana. However, it should be noted that Ghana may have similar financial institutional development with other developing countries in Africa; hence, the outcome of the current research can be applied to other economically developing nations in the world. Therefore, it is very crucial to consider the possibility of variations in monetary institutional development among the economically developing nations in hope that it can produce a more desirable outcomes. Furthermore, it may be fruitful to repetitively incorporate this study framework by relying on data from other SMEs sectors such as manufacturing and agriculture from other developing countries. Third, another interesting limitation of this study was the lack of discovery on the measurement of monetary proficiency; hence, it is important to be further discovered in future works. On another note, the present study only utilized three items to measure financial literacy due to the context relevancy which included records keeping, working capital management, and financial investment decision. Therefore, future studies can incorporate other items such as budgeting, financial statement preparation, financial statement analysis and financial statement review which could influence the effect of financial resource availability on growth. Finally, future studies need to develop a more comprehensive measurement of monetary proficiency.

\section{CONCLUSION}

In summary, the results of the current research showed a clear agreement on the notion that resource availability acts as the key predictor of firm growth and internationalization of local SMEs, which should 
be developed as the central focus of entrepreneurial activities. Hence, SMEs owners should recognize and intensify their quest of mobilizing financial resources. Apart from that, the present study also challenged both scholars and entrepreneurs to embark on the learning process of financial management seriously considering its significant impact on the growth and internationalization of local SMEs in developing countries.

\section{ACKNOWLEDGEMENT}

This study was partially supported by the Research University's Individual Grant (1001/PPSP/812149) from the Universiti Sains Malaysia.

\section{REFERENCES}

1. Adomako, S., \& Danso, A. (2014). Financial literacy and firm performance: The moderating role of financial capital availability and resource flexibility. International Journal of management and organizational studies, 3(4), 1-15. http://hdl.handle.net/2086/13895

2. Aktas, N., Croci, E., \& Petmezas, D. (2015). Is working capital management value enhancing? Evidence from firm performance and investments. Journal of Corporate Finance, 30, 98113. https://doi.org/10.1016/j. jcorpfin.2014.12.008

3. Anderson, J. C., \& Gerbing, D. W. (1988). Structural equation modeling in practice: A review and recommended two-step approach. Psychological Bulletin, 103(3), 411-423. https://doi. org/10.1037/0033-2909.103.3.411

4. Bagozzi, R. P., \& Yi, Y. (2012). Specification, evaluation and interpretation of structural equation odels. Academy of Marketing science, 40(1), 8-34. https://doi.org/10.1007/s11747011-0278-x

5. Barney, J., \& Hesterly, W. (2012). Strategic management and competitive advantage: concepts and cases (4th ed.). Upper Saddle River, NJ: Prentice Hall.

6. Barney, J. B. (1991). Firm Resources and Sustained Competitive Advantage. Journal of Management, 17(1), 99120. https://doi.org/10.1177\% 2F014920639101700108
7. Beamish, P. W. (1990). The internationalization process of smaller Ontario firms: A research agenda. In A. M. Rugman (Ed.), Research in global strategic management (pp. 77-92). Greenwich: JAI Press.

8. Beck, T., Demirguc-Kunt, A., \& Maksimovic, V. (2008). Financing patterns around the world: Are small firms different? Journal of Financial Economics, 89(3), 467-487. https://doi.org/10.1016/j. jfineco.2007.10.005

9. Boso N., Storey, V. M., \& Cadogan, J. W. (2013). Entrepreneurial orientation, market orientation, network ties and performance. Journal of Business Venturing, 28(6), 708-727. https://doi. org/10.1016/j.jbusvent.2013.04.001

10. Bottazzi, G., \& Secchi, A. (2003). Common properties and sectoral specificities in the dynamics of US manufacturing companies. Review of Industrial Organization, 23(3-4), 217-232. https://link. springer.com/article/10.1023/ B:REIO.0000031366.28559.c1

11. Byrd, K., Ross, L., \& Glackin, C. (2013). A preliminary causal analysis of small business capitalisation structures and patterns. Journal of Applied Finance \& Banking, 3(5), 7784. Retrieved from https:// www.researchgate.net/ publication/281101954_A_ Preliminary_Causal_Analysis_ of_Small_Business_Access_ to_Credit_during_Economic Expansion_and_Contraction
12. Cadogan, J. W., \& Lee, N. (2013). Improper use of endogenous formative variables. Journal of Business Research, 66(2), 233241. https://doi.org/10.1016/j. jbusres.2012.08.006

13. Campbell, J. Y. (2006). Household Finance. Journal of Finance. Retrieved from https://www.nber. org/papers/w12149.pdf

14. Coleman, J. (2007). Social capital in the creation of human capital. American Journal of Sociology, 94, 95-120. Retrieved from http:// links.jstor.org/sici?sici=00029602\%281988\%2994\%3CS95\%3AS CITCO\%3E2.0.CO\%3B2-P

15. Coleman, S., Cotei, C., \& Farhat, J. (2013). A resourced-based view of new firm survival: new perspectives on the role of industry and exit route. Journal of Developmental Entrepreneurship, 18(1). https://doi.org/10.1142/ S1084946713500027

16. Cooper, M., \& Klomp, L. (1994). Small business and job creation: a comment. Small Business Economics, 8(4), 317-322.

17. Davidsson, P., Delmer, F., \& Wiklund, J. (2006). Entrepreneurship and the growth of firms. Northampton, MA: Edward Elgar.

18. Delmar, F. (1997). Measuring growth: methodological considerations and empirical results. In R. Donckels \& A. Miettinen (Eds.), Entrepreneurship and SME Research: On Its Way to the Next Millennium (pp. 199-216). Ashgate, Aldershot. 
19. Delmar, F., Davidsson, P., \& Gartner, W. (2003). Arriving at the High-growth Firm. Journal of Business Venturing, 18(2), 189-216. https://doi.org/10.1016/S08839026\%2802\%2900080-0

20. Demirgüç-Kunt, A., Aslı, L. K., \& Dorothy, S. (2013). Financial Inclusion and Legal Discrimination against Women: Evidence from Developing Countries (World Bank Policy Research Working Paper, 6416).

21. Dollinger, M. J. (1999). Entrepreneurship: strategies and resources. Upper Saddle River, NJ: Prentice Hall.

22. Drexler, A., Fischer, G., \& Scholar, A. (2014). Keeping it simple: financial literacy and Rules of Thumb. American Economic Journal: applied Economics, 6(2), 1-31. https://doi.org/10.1257/ app.6.2.1

23. EC (2007). Final report of the expert group on supporting the internationalization of SMEs. Brussels: Directorate-General for Enterprise and Industry of the European Commission.

24. Eisenhardt, K. M., \& Tabrizi, B. N. (1995). Accelerating adaptive process: process innovation in the global computer industry. Administrative Science Quarterly, 40(1), 84-110. https://doi. org/10.2307/2393701

25. Fatoki, O. (2014). The financial literacy of Micro Entrepreneurs in South Africa. Journal of Social Sciences, 40, 151-158. https://doi.org /10.1080/09718923.2014.11893311

26. Fjose, S., Grunfeld, L. A., \& Green, C. (2010). SMEs and growth in Sub-Sahara Africa: Identifying SME Role and obstacles to SME growth. MENON-Publication, 14, 1-28.

27. Fornell, C., \& Larcker, D. F. (1981) Structural equation models with unobservable variables and measurement error: Algebra and statistics. Journal of Marketing Research, 18(3), 382-388. https://doi. org $/ 10.2307 / 3150980$

28. George, G. (2005). Slack resources and the performance of privately held firms. Academy of Management Journal, 48(4),
661-676. https://doi.org/10.5465/ amj.2005.17843944

29. Ghana Statistical Service (2016). Integrated Business Establishment Survey. Regional Spatial Business Report.

30. Greenspan, A. (2002). Financial Literacy: A Tool for Economic Progress. The Futurist, 36(4), 37-41. Retrieved from https:// www.researchgate.net/ publication/293423616_Financial_ literacy_A_tool_for_economic progress

31. Hair, J. F., Hult, G. T. M., Ringle, C. M., \& Sarstedt, M. (2014). A Primer on Partial Least Squares Structural Equation Modeling (PLSSEM). Thousand Oaks, CA: Sage Publications, Inc.

32. Hilgert, M., Hogarth, J., \& Bervely, S. (2003). Household financial management: the connection Between knowledge and behaviour. Federal Reserve Bulletin, 309-332. Retrieved from https://econpapers. repec.org/article/fipfedgrb/ y_3a2003_3ai_3ajul_3ap_3a309322_3an_3av.89no.7.htm

33. Kozlenkova, I., Samaha, S., \& Palmatier, R. (2013). Resourcebased theory in marketing. Academy of Marketing Science Journal, 42(1), 1-21. https://doi. org/10.1007/s11747-013-0336-7

34. Krishnan, R., Martin, X., \& Noorderhaven, N. G. (2006). When does trust matter to alliance Performance? Academy of Management Journal, 49(5), 894-917. https://doi.org/10.5465/ amj.2006.22798171

35. Little, T. D., Bovaird, J. A., \& Widaman, K. F. (2006). On the merits of orthogonal zing powered and product terms: Implications for modeling interactions among latent variables. Structural Equation Modeling, 13(4), 497 519. https://doi.org/10.1207/ s15328007sem1304_1

36. Lusardi, A., \& Tufano, P. (2008). Debt Literacy, Financial Experience and Over-Indebtedness (Working Paper No. 14808).

37. Lusardi, A., \& Mitchell, O. S. (2011) Financial Literacy and Planning: Implications for Retirement
Wellbeing. In Financial Literacy: Implications for Retirement Security and the Financial Marketplace (pp. 17-39). Oxford: Oxford University Press.

38. Lusardi, A., \& Mitchell., O. S. (2013). The Economic Importance of Financial Literacy. Theory and Evidence (NBER Working Paper 18952).

39. Lusardi, A., Mitchell, O. S., \& Curto, V. (2010). Financial literacy among the young. Journal of Consumer Affairs, 44(2), 358-380. Retrieved from https://www.nber. org/papers/w15352

40. Makadok, R. (2001). Toward a synthesis of the resourcebased and dynamic-capability view of rent creation. Strategic Management science, 22(5), 387-401. Retrieved from https://www.jstor.org/ stable/3094265?seq=1\#page_scan_ tab_contents

41. Miller, M., Godfrey, N., Levesque, B., \& Stark, E. (2009). The case of financial literacy in developing countries: Promoting Access to Finance by Empowering Consumers. World Bank, DFID, OECD and CGPA joint note. Washington DC.

42. Nunally, J. C. (1978). Psychometric Theory (2nd ed.). New York: McGraw Hill Book Company.

43. Penrose, E. T. (1959). The theory of the growth of the firm. New York: Sharpe. Oxford, UK: Oxford University Press.

44. Podsakoff, M. P., Mackenzie, B, S., \& Lee, J. Y. (2003). Common Method Bias in Behavioural Research: a critical review of the literature and recommended remedies. Journal of Applied Psychology, 88(5), 879-903. Retrieved from https://psycnet. apa.org/doi/10.1037/00219010.88.5.879

45. Shafeey, T. E., \& Trout, P. (2014). Resource-based competition: Three schools of thought and thirteen criticisms. European Business Review, 26(2), 122-148. https://doi.org/10.1108/EBR-072013-0096

46. Storey, D. J. (1994). Understanding the Small Business Sector. Thomson Learning Emea. 
47. Sucuahi, W. T. (2013).

Determinants of financial literacy of micro entrepreneurs in Davao City. International Journal of Accounting Research, 1(1), 44-45. Retrieved from https://www. omicsonline.org/open-access/ determinants-of-financialliteracy-of-microentrepreneursin-davao-city-.php?aid=15865

48. Van Rooij, M. C. J, Lusardi, A., \& Alessi, R. J. M. (2011). Financial Literacy and Retirement Planning in the Netherlands. Journal of Economic Psychology, 32, 593 608. https://doi.org/10.1016/j. joep.2011.02.004

49. Wakkee, I., Van Der Veen, M., \& Eurlings, W. (2015). Effective growth path for SMEs. The
Journal of Entrepreneurship, 24(2), 169-185. https://doi.org/10.1177\%2F0971355715586894

50. Wernerfelt, B. (1984). A resource-based view of the firm. Strategic Management Journal, 5(2), 171-180. Retrieved from https://www.jstor.org/ stable/2486175?seq=1\#page_scan_ tab_contents

51. Wiklund, J., \& Shepherd, D. A. (2005). Entrepreneurial orientation and small business performance: a configurational approach. Journal of Business Venturing, 20(1), 71-91. https://doi. org/10.1016/j.jbusvent.2004.01.001

52. Wiklund, J., \& Shepherd, D. A. (2007). Where to from here?
EO-as- experimentation failure and distribution outcomes. Entrepreneurship Theory and Practice, 35(5), 925-946. https:// doi.org/10.1111\%2Fj.15406520.2011.00454.x

53. Yasuda, T. (2005). Firm growth, size, age and behaviour in Japanese manufacturing. Small Business Economics, 24(1), 1-15. Retrieved from https://www.jstor. org/stable/40229405?seq=1\#page scan_tab_contents

54. Yazdanfar, D., \& Habib, K. (2016) Determinant of SMEs growth; the influence of financing pattern. An empirical study based on Swedish data. Management of Research Review, 39(5), 966-986. http:// dx.doi.org/10.1108/MRR-04-20150093 